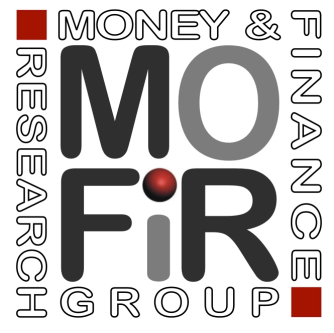

Do BANKS PRICE Discriminate SPATIALly? EVIDENCE FROM SMALL BUSINESS LENDING IN LOCAL CREDIT MARKETS

Andrea Bellucci Alexander Borisov

Alberto Zazzaro

Working paper no. 79

February 2013 


\title{
Do Banks Price Discriminate Spatially? Evidence from Small Business Lending in Local Credit Markets ${ }^{i}$
}

\author{
Andrea Bellucci ${ }^{\mathrm{a}}$, Alexander Borisov ${ }^{\mathrm{b}}$, Alberto Zazzaro ${ }^{\mathrm{c}, \mathrm{ii}}$ \\ ${ }^{a}$ University of Naples Federico II \\ ${ }^{\mathrm{b}}$ University of Cincinnati \\ c,ii Polytechnic University of Marche and Money and Finance Research group (MoFiR)
}

This version: 2 February 2013

\begin{abstract}
In this paper we explore the effects of bank-borrower physical proximity on price and non-price aspects of small business lending in local credit markets. Along the price dimension, our analysis reveals that interest rates increase with bank-borrower distance and decrease with the distance between borrower and other competing banks. Along the quantity dimension, we observe that more distant borrowers are more likely to experience binding credit limits. We also show that the quantity effects of bank-borrower distance are concentrated among less transparent firms. Our findings are consistent with pricing based on marginal costs that reflect information-based factors, and are in contrast to the established paradigm, where banks adopt spatial discriminatory pricing rules when lending to small-sized enterprises.
\end{abstract}

JEL Classification: G21, G32, L11

Keywords: Distance, Bank lending, Pricing, Interest rate, Credit availability

\footnotetext{
${ }^{i}$ We are grateful for comments and suggestions from Giorgio Calcagnini, Giuseppe Coco, Ilario Favaretto, Michele Fratianni, Iftekhar Hasan, Celine Meslier, Andrea Presbitero, Alain Sauviat, Amine Tarazi, Gregory Udell, and participants at the XXI Conference on Money Credit and Banking (Rome), and seminars held at the Polytechnic University of Marche, University of Limoges, University of Naples Federico II, and University of Urbino. All remaining errors are our own.

ii Corresponding author; tel. +39-071-220-7086; fax +39-071-220-7102. E-mail addresses: andrea.bellucci@uniurb.it (Andrea Bellucci), alexander.borisov@uc.edu (Alexander Borisov), a.zazzaro@univpm.it (Alberto Zazzaro).
} 


\section{Introduction}

The last thirty years have witnessed a process of extraordinary advancement in information and communication technologies. This has led the banking industry to a widespread adoption of various mechanisms for impersonal service delivery (e.g., phone and internet banking, automated teller machine networks) and screening technologies (e.g., automated credit scoring models). Despite this technological transformation, the physical proximity between borrowers and their lending banks, and other banks in the local credit market remains a major factor for the outcome of the lending transaction (Alessandrini et al. 2009; Cerqueiro et. al. 2009).

In general, the importance of geographic distance for the process of economic exchange is attributable to the presence of transaction costs, related to transportation of economic agents and products, and information frictions. Extant research in the banking field offers robust evidence on the existence and significance of such costs (e.g., Petersen and Rajan 2002; Brevoort and Wolken 2009). By contrast, the exact nature of the costs of borrower-lender distance, i.e. whether they reflect information frictions, transportation factors, or both, and how these costs influence the pricing and supply of bank loans remain open questions. In this paper we address these two questions about the role and nature of the costs of distance in the context of small business lending. First, we establish how these costs are incorporated in the pricing of bank loans. Second, by examining the availability of credit and its degree of tightness, we infer whether the effect of distance is more likely to reflect transportation or information factors.

There are two main arguments why distance between the contracting parties is relevant for the cost of bank credit. First, physical proximity affects the transportation costs borrowers and loan officers face when they complete and manage transactions in person (Chiappori et al. 1995; Sussman and Zeira 1995; Almazan 2002). Second, information and search costs borrowers incur in order to learn about products and loan conditions offered by other banks in the local market decrease with the geographic closeness between the borrower and these banks (Gehrig 1993). More importantly, the amount and precision of information available to the lending officer is directly related to the proximity between the officer and borrower's economic and social environment (Almazan 2002; Dell'Ariccia and Marquez 2004; Hauswald and Marquez 2003, 2006). Besides, the magnitude of information asymmetry concerns such as "winner's curse" can also be related to the distance between borrower and bank's competitors (Shaffer 1998). This affects the quality of information and the need for visiting borrowers frequently, which implies that presence of nearby competitors could increase the information and transportation costs for the lending bank. 
Regardless of the precise nature and source of the costs of distance, their impact on loan interest rates should depend on the underlying pricing model adopted by the lending bank. Specifically, the main distinction should be drawn based on whether banks price discriminate borrowers spatially by location or, alternatively, price loans according to marginal costs.

In case of spatial discriminatory pricing, banks exploit their monopoly power over nearby borrowers obtained from transportation and/or informational advantages. Banks can thus charge such borrowers higher interest rates (Lederer and Hurter 1986; Dell'Ariccia et al. 1999; Degryse et al. 2009). The market-power effects of distance should also depend on the location of the other competing banks in the local credit market. When nearby alternative lending sources are available, the transportation and information advantages of the lending bank, and thus the interest rate it may charge, should be lower.

Different prediction arises when banks set interest rates following a simple rule of mark-up over marginal cost. Loan rates should be positively associated with borrower-lender distance if the marginal costs increase with this distance. By contrast, the distance between a borrower and competitors of the lending bank has an ambiguous effect on the interest rate. On the one hand, concerns about the possible realization of "winner's curse" are mitigated when a borrower is farther away from bank's competitors. This lowers the costs faced by the lending bank. On the other hand, the lending bank may increase the mark-up as switching banks is more costly for borrowers located farther away from other potential lenders (Barone et al. 2011).

Recently, a number of studies have examined empirically how loan rates and credit supply vary with the geographic proximity between borrower and lender. In their seminal paper on the changing importance of distance for small business lending, Petersen and Rajan (2002) show a significant increase in the average (but not median) distance between borrower and lender in the US context. They also find that firms that are able to borrow at distance pay lower interest rates and have higher chances of seeing their loan applications approved. The study captures ability to borrow at distance as the predicted value of a regression of observed distance from lenders on measures of public information about the borrower. In this perspective, the findings suggest that the impact of distance on interest rates and credit availability reflects banks' proprietary information and borrowers' transparency, rather than spatial discriminatory pricing.

Agarwal and Hauswald (2010) analyze the lending decisions of a major US bank about loan applications by small corporate borrowers. The study shows that applicants close to the lending branch pay higher interest rates but are also more likely to obtain credit. Consistent with information-based theories, this pattern disappears once the analysis accounts for loan officers' proprietary information, measured by the component of borrowers' assigned credit scores 
orthogonal to public information about their credit quality. Since the authors consider the actual distance between applicant and bank branch, and control for distance to the nearest rival of the bank, their findings are supportive of information-based models of discriminatory pricing (Dell'Ariccia and Marquez 2004; Hauswald and Marquez 2006).

Degryse and Ongena (2005) study the pricing behavior of a large Belgian bank with respect to loans made almost exclusively to individual and small businesses and document that interest rates decrease (increase) with the distance between the borrower and lending bank (competing banks). The effects of distance appear to be mainly driven by transactional loans, and almost non-existent for loans that are more likely to be relationship-based, and thus more informationsensitive. The authors interpret their findings as consistent with models of spatial price discrimination and banks internalizing transportation costs for nearby borrowers. In a subsequent study analyzing loan contracts from the same bank, Degryse et al. (2009) provide further evidence in favor of spatial discriminatory pricing driven by transportation costs. In particular, they show that the association between borrower's distance to competing banks and loan interest rates decreases when the rival banks are hierarchically organized. To the extent that such banks are more likely to make lending decisions using hard information (Stein 2002), the number and frequency of required in-person meetings between borrower and loan officer should decrease, thus lowering the market power of the lending bank.

In contrast to the above studies, Knyazeva and Knyazeva (2012) focus on syndicated loans to large firms and find that interest rates are positively associated with the geographic distance between the borrowing firm and its lead lender (or the average distance to the pool of lenders). ${ }^{1}$ The authors advance the argument that this pattern reflects the increasing costs of delegated monitoring that banks have to incur when dealing with borrowers located farther away.

Overall, the available empirical evidence suggests an interesting dichotomy. Banks seem to follow spatial discriminatory pricing when lending to small- and mid-sized enterprises (SMEs). Such borrowers are usually more opaque from an informational point of view, require in-person contacts and interactions, and are typically restricted to access only the local credit market where they reside. By contrast, banks appear to price loans on the basis of marginal cost when lending to large corporations. Information, transportation and switching costs should be less important on the margin for these clients.

In this paper, we present findings that raise a question about the pricing paradigm that appears in the literature. Specifically, our analysis provides evidence consistent with marginal cost pricing for small business loans. We analyze a large proprietary dataset of loans granted by a

\footnotetext{
1 Similarly, Giannetti and Yafeh (2012) document that the interest rates on large international syndicated loans are positively associated with the cultural distance between the borrower and lead lender.
} 
major inter-regional Italian bank to SMEs in the period 2004-2006 and find that interest rates increase with the borrower-lender distance and decrease with the distance between borrower and competing banks in the local credit market. This suggests that physical distance from the lending branch represents a non-trivial cost in the lending relationship that banks transfer onto their borrowers.

The second step of our analysis investigates the quantity dimension of the bank-borrower interaction, captured through the probability that a borrower faces tight credit availability and has to use the costly option to overdraw funds over the granted credit line. The quantity perspective allows us to offer some insight into the economic factors - transportation or information - that underlie the costs of distance. Our identification strategy rests on the following idea. If distance reflects pure transportation costs, the credit constraints faced by borrowers, and thus likelihood of overdrawing, should not be affected by their location as these costs can be more easily quantified and reflected in the price-setting process, making credit supply and demand roughly aligned. Conversely, if bank-borrower distance is a proxy for information asymmetry and its costs, banks should be more restrictive in lending to borrowers located farther away. Hence, the probability that such borrowers overdraw funds, i.e. face tighter credit availability, should be higher.

In contrast to the effects of physical proximity on interest rates, the implications of distance for loan availability and credit tightness are not extensively analyzed in the literature. Carling and Lundberg (2005) develop a model of geographic credit rationing based on the premise that information asymmetry is mitigated in the vicinity of the bank. As a result, more distant borrowers are subject to stricter lending standards and increased likelihood of rationing. However, their empirical analysis, using data from a large Swedish bank, does not detect evidence of such practices. By contrast, Brevoort and Hannan (2006) and Agarwal and Hauswald (2010) observe that the likelihood of loan approval increases (diminishes) with the geographic proximity between applicant and lender (competing banks). However, they do not analyze the amount of credit granted and the degree of credit tightness.

Consistent with the information-based arguments, our analysis reveals that the degree of credit tightness is affected by borrowers' physical location. The probability of borrowers facing a binding credit limit, and overdrawing, increases with their physical distance from the bank and decreases with their distance from other competing banks in the local credit market.

If distance affects the outcome of the lending process through information-based costs, one should expect its effect to be stronger for cases where such costs dominate. Therefore, to substantiate our insights, we explore the cross-sectional heterogeneity in the degree of opacity of 
our sample borrowers. To this end, we split our sample into categories based on characteristics (e.g., size and rating availability) intended to capture borrower's opacity and the magnitude of information asymmetry, and repeat our analysis. We find that the effects of distance are more pronounced for the types of borrowers that can be considered as less transparent. This result further corroborates our conclusion that distance represents information-based costs of the bank-firm lending relationship.

The rest of the paper is organized as follows. In the next Section, we describe our data and variables. The empirical strategy is discussed in Section III. We present our main results and some robustness tests in Section IV. Section V concludes.

\section{Data and variables}

\section{A. Dataset}

To examine the costs of physical distance in the context of small business lending, we utilize a unique proprietary dataset of credit lines granted to SMEs by a major inter-regional Italian bank (hereafter, simply the bank) as of September 2004 and 2006. The dataset covers the bank's entire portfolio of credit lines in two Italian provinces, managed by more than 60 bank branches. ${ }^{2}$ One of the bank's core businesses is provision of financing to SMEs and this makes the dataset ideal for the purposes of our analysis. Consequently, almost $43 \%$ of the borrowing firms are Sole Proprietorships, accounting for $25 \%$ of the loans granted by the bank. Other organizational forms present in our sample are Partnerships (28\%) and Corporations (33\%) accounting for 35\% and 38\% of the total loans granted by the bank, respectively. The remaining borrowing firms are cooperatives. Our sample includes firms from more than 23 sectors of economic activity defined at the 2-digit level according to the Italian National Institute of Statistics (ISTAT). ${ }^{3}$

The dataset includes information on loan contract terms (e.g. credit limit, interest rate, collateral), various aspects of the bank-borrower relationship (e.g. length and exclusivity, whether the borrower uses other services from the bank), borrower characteristics (e.g. location, sales, industry specialization, organizational form), and characteristics of the local credit market and lending branch (e.g. location). We augment the dataset provided by the bank with information on the distance between each borrower and all branches in the local credit market. It should be noted that our dataset only contains information on approved contracts but not on applications. Nevertheless, the richness of the data in terms bank and borrower characteristics and local credit

\footnotetext{
${ }^{2}$ Less than $4 \%$ of the credit lines are granted to firms located outside these two provinces. We should note that the provinces are representative of the Italian economic structure characterized by a large number of SMEs.

${ }^{3}$ A sub-set of less than half of the borrowers has been used to study the relevance of gender of contracting parties involved in bank lending (see Bellucci et al. 2010). The focus of the sub-set was exclusively on sole proprietorships, where borrower's gender could be uniquely identified.
} 
market conditions, allows us to analyze the impact of bank-borrower distance on loan pricing and the nature of distance costs.

\section{B. Dependent variables}

We focus on two outcome variables concerning credit lines: price and availability of credit. Summary statistics for these (and all other) variables are reported in Table 1. First, we use the interest rate charged by the bank to measure the price of credit. The average Interest Rate for our borrowers is $7.06 \%$. The second outcome variable relates to the quantity dimension of the loan contract. We focus on the incidence of binding credit limits and thus, on the probability that a borrower experiences tight credit availability. To this end, we construct a variable Overdraw as an indicator that takes the value of 1 if a borrower draws more credit than what is actually granted by the bank according to the contract, and 0 otherwise. For overdrawing firms, credit availability may be considered as tighter as borrowers exceeding their credit limit incur fees and penalty rates. On average, $22 \%$ of the borrowers in our sample face tight credit availability, i.e. overdraw funds. Relatedly, the average credit limit in our sample is $€ 86,511$ with substantial variation across organizational forms (€49,065 for sole proprietorships and $€ 101,438$ for corporations). The average amount of credit actually used is $€ 62,268$, equivalent to $72 \%$ of the amount allowed by bank ( $€ 38,924$ for sole proprietorships and $€ 66,454$ for corporations - equivalent to $79.33 \%$ and $65.51 \%$, respectively). We also note that partnerships and sole proprietorships are more likely to exceed their credit limit, compared to corporations (24.04\% vs. $20.85 \%$ ).

Overdrawing borrowers are also more likely to be located outside their local credit market, rather than inside $(25.04 \%$ vs. $21.19 \%)$. As a result, they are also farther away from the lending branch. This is consistent with the argument that lenders obtain more precise signals about closer firms and could monitor these firms better, while the precision of the signal about the nature and activities of a borrower likely deteriorates for more distant firms. As a result, there is a (partial) reduction of credit availability for such borrowers.

\section{Distance variables}

We capture the importance of physical distance in two ways. First, we measure the distance between the bank and each borrower (Branch-Firm Distance). Using the exact geographic location of borrower and lending branch, we compute the metric distance that separates them. The distance is based on the shortest and fastest route, and is obtained through Routemate. ${ }^{4}$ The average distance between a borrower and our bank is almost $4.98 \mathrm{~km}$ (3.09 miles). Bank-firm

\footnotetext{
${ }^{4}$ Routemate is software for optimization of transportation costs and calculation of distance. For more information about the software, please see http://en.nemsys.it/prodotti.html
} 
distance varies considerably with firm's organizational form, sales and the firm's classification in the bank's loan portfolio (small-business portfolio or corporate portfolio). The average distance is $4.66 \mathrm{~km}$ (2.89 miles) for sole proprietorships and $5.79 \mathrm{~km}(3.60$ miles) for corporations. For micro-firms with sales less than $€ 250,000$, the branch-firm distance is $4.56 \mathrm{~km}$ (3.83 miles) on average. This magnitude is $6.62 \mathrm{~km}$ (4.11 miles) for firms with sales higher than $€ 5$ million. Considering various components of bank's loan portfolio, we note that the average distance is $4.79 \mathrm{~km}$ (2.98 miles) for borrowers in the small-business portfolio and $6.84 \mathrm{~km}$ (4.25 miles) for borrowers in the corporate portfolio.

We construct Rivals-Firm Distance to capture the distance between borrower and competing banks operating in the local credit market, defined as the municipality where the borrower resides or the postal code of the borrower if this covers multiple small municipalities. To this end, we first identify all bank branches in the local credit market for each borrower in our sample. We then calculate the distance from each of these branches to the borrower. We measure a borrower's distance to competing banks with the $25^{\text {th }}$ percentile of these distances. Focusing on the $25^{\text {th }}$ percentile, rather than on the minimum distance, allows for inferences that are more robust and less sensitive to outliers. The average distance to competing banks for the borrowers in our sample is approximately $3.34 \mathrm{~km}$ (2.08 miles). In $86 \%$ of the cases, a borrower is located closer to the branch of a competing bank than to the branch of our bank. In $73 \%$ of the cases, the firm and the loan-granting branch are in the same local credit market.

\section{Control variables}

Cost of credit depends on various factors related to borrower and lender characteristics, as well as to market and business cycle conditions. In order to ensure that our distance metrics do not simply capture some of these factors, we use a broad set of control variables reflecting borrower characteristics and the nature of the bank-borrower interaction. In addition to that, we include industry, branch, market, and year fixed effects. Unfortunately, we cannot include borrower fixed effects. During the time period of the study, our bank did not pursue significant organizational restructuring in terms of closing existing branches or opening new ones. As a result, only $1 \%$ of the borrowers in our sample are observed to change the bank branch from which they borrow. This makes our variable of interest, Branch-Firm Distance, quasi-time-invariant, and renders the use of within estimators infeasible. In an attempt to take into account unobservable individual effects, we use random effects and Hausman-Taylor estimators.

Our control variables reflect various borrower characteristics and the nature of the bankborrower relationship. Firm size is measured by borrower's total sales (Sales). As the bank only 
provides sales categories rather than exact amounts, we construct a step variable which takes the value of 1 if the sales are less than $€ 250,000,2$ for sales between $€ 250,000$ and $€ 1,500,000,3$ for sales between $€ 1,500,000$ and $€ 5,000,000,4$ for sales between $€ 5,000,000$ and $€ 25,000,000,5$ for sales between $€ 25,000,000$ and $€ 50,000,000$. As our focus is on small business lending, we follow the EU definition of Small Business Enterprises and exclude from our dataset borrowers with sales exceeding $€ 50,000,000{ }^{5}$ The average borrower in our sample falls in the second category. However, firms with sales below $€ 250,000$ represent $54.9 \%$ of the sample. The fraction of sample firms in each of the remaining categories is as follows: $10.6 \%$ in category $2,14.6 \%$ in category $3,11.7 \%$ in category $4,8.4 \%$ in category 5 , and $2.6 \%$ in the last category. In the multivariate analysis, we use separate indicators for each sales category rather than the step variable. Specifically, we construct indicators $D$ (Sales i) that take the value of 1 if the borrower's sales are in the $i$-th category, and 0 otherwise. This approach allows us to better capture the effect of firm size without imposing the restriction that a shift from one category to the next has a constant effect across categories.

As another borrower characteristic, we consider their organizational form. Corporation is an indicator that takes the value of 1 if the loan recipient is a corporation and 0 otherwise. $33 \%$ of the borrowers have this organizational form.

We next introduce three measures intended to capture the nature of the bank-borrower lending relationship. First, Relationship Length is the number of days since the firm has first borrowed from our bank. On average, our sample firms have been clients of the bank for 3,360 days. This is comparable to the findings by Cole (1998) and Degryse and Van Cayseele (2000) that the average bank-borrower relationship is between 7 and 8 years. For Italy, Gambini and Zazzaro (2012) document that firms with fewer than 50 employees maintain credit relationships with their bank for 12 years on average. In the multivariate analysis, we take a logarithmic transformation of this variable. Second, Multiple Lending is designed to capture the exclusiveness of the bank-borrower relationship. The variable takes the value of 1 if the firm borrows from multiple banks and 0 if the firm has an exclusive relationship with our bank. Consistent with the well-documented prevalence of multiple lending across Italian firms (Detragiache et al. 2002), only $4 \%$ of the firms in our sample have an exclusive lending relationship with the bank. Lastly, Other Services considers the scope of bank-borrower interaction. The variable takes the value of 1 if the firm uses additional services provided by the bank, and 0 otherwise. Only $9 \%$ of the firms merely borrow from the bank without using additional services.

\footnotetext{
5 The European Commission adopted the definition of Small Business Enterprises in its Recommendation of 6 May 2003 (GUCE L 124/36 del 20/05/2003).
} 
Existing research documents the importance of banks' organizational structure and decision making process (e.g., Liberti and Mian 2009). First, we take into account the hierarchical position of the lending branch in the bank's organizational structure. The network of branches of our bank is distributed across local credit markets and is coordinated by regional headquarters. Each branch has decision-making power with respect to the credit lines extended by its loan officers. However, the headquarters of the bank might have more services or more efficient monitoring, which could affect the cost structure and thus ability to offer credit at a lower price. Alternatively, the headquarters might adopt more formal or impersonal modes of interaction with clients in comparison to smaller local bank branches. To account for possible effect of such differences on loan contract terms, we construct an indicator Decisional Level that takes the value of 1 if a credit line is managed at the regional headquarters and 0 if this happens at a local bank branch. $17.1 \%$ of the credit lines are managed at the headquarters.

In addition to the measure of hierarchical level responsible for managing a credit line, we also create the variable Porffolio that identifies the market segment, from bank's point of view, where a borrower falls. Specifically, the variable takes the value of 1 if the bank considers the credit line as part of its corporate market and 0 if it is part of the small business market. The small business market represents about $91 \%$ of the loan portfolio. It is important to note that the bank might consider a firm with corporate organizational form as part of its small business market due to the firm's characteristics and required services. The distinction has implications for the riskiness of the loan and for the internal division that manages the credit line and the resources devoted to it.

Lastly, to control for loan contract risk, we consider the collateralization of the credit line. Existing studies advance several contrasting explanations for the association between loan risk, collateral and interest rate, depending on whether collateral requirement is viewed as a screening device or insurance policy. Collateral, which measures the degree of collateralization of the credit line, is a step variable that takes the value of 1 if the credit line is not collateralized, 2 if it is collateralized up to $80 \%$ of the credit limit, and 3 if the collateral amount exceeds $80 \%$. In the multivariate analysis, we use indicator variables for each category of collateralization. Specifically, $D$ (Collateral $i)$ takes the value of 1 if the collateralization of a credit line falls in the $i$-th category. Note that $70 \%$ of the credit lines are not covered by collateral, i.e. fall in category 1 . The fraction of credit lines in the $2^{\text {nd }}$ and $3^{\text {rd }}$ categories is $19 \%$ and $11 \%$, respectively.

The summary statistics for all outcome variables of interest and the controls are presented in Table 1. The construction of the variables is summarized in the Appendix. 


\section{Empirical models}

The first part of our analysis is to examine whether and how price of credit reflects the physical proximity between the transacting parties in the lending process and between borrower and bank rivals. If banks discriminate spatially, or exploit their local monopoly and information advantage, interest rates should be higher in the vicinity of the lending bank and lower in the vicinity of its rivals. By contrast, if banks price competitively based on marginal costs and these costs are increasing (decreasing) in geographic distance from the lending bank (bank's rivals), interest rates should be lower in the vicinity of a lender and higher in the vicinity of its rivals. To distinguish between these alternatives, we estimate the following ordinary least squares (OLS) model:

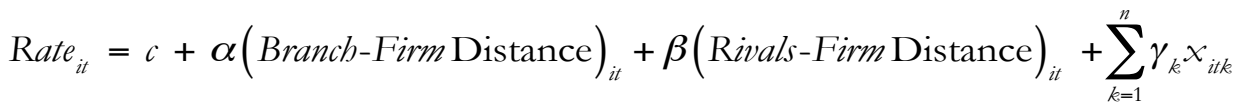

$$
\begin{aligned}
& +\sum_{s=1}^{m} \phi_{s} \text { Industry }_{i s}+\sum_{b=1}^{h} \varphi_{b} \text { Branch }_{i b}+\sum_{m=1}^{z} \eta_{j} \text { Market }_{i m}+\tau \text { Time }_{i}+\varepsilon_{i t}
\end{aligned}
$$

where Rate is the interest rate in percentage paid by borrower $i$ at time $t$. Branch-Firm Distance is the natural logarithm of the distance that separates the borrower from the lending branch. RivalsFirm Distance is the $25^{\text {th }}$ percentile of the distribution of distances between the borrower and all other banks in local credit market. $x$ is a vector of firm-specific characteristics (sales, activity sector, organizational form, etc.) and bank-firm relationship factors (credit limit, services, rating, exclusivity of relationship, length, riskiness, portfolio, decisional level, etc.). We include industry, branch, market and time fixed effects.

Negative (positive) point estimate of $\alpha(\beta)$ in equation (1) would be consistent with lending practices of spatial price discrimination. The reverse relationship $(\alpha>0$ and $\beta<0)$ should hold if the bank follows marginal cost pricing.

In the second step of our analysis, we try to identify the nature of the costs raised by distance. Specifically, we focus on the quantity dimension of the loan contract. The underlying rationale is that, in contrast to information-based costs, costs that are not information-based (e.g., transportation costs) can be measured relatively more easily and thus can be reflected in the price of credit. Hence, there should be no implication for the likelihood of overdrawing. To investigate, we estimate a Probit model for the probability that a borrower uses credit in excess of what is made available by the bank, i.e. overdraws funds, as follows: 


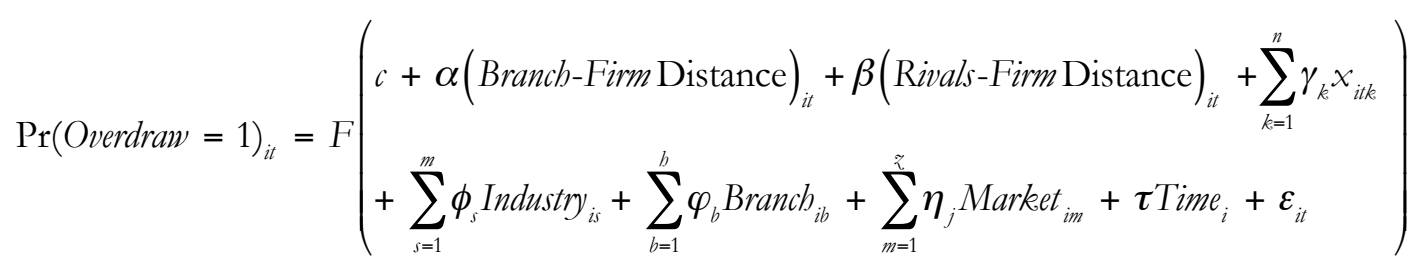

where Overdraw is an indicator that takes the value of 1 if a borrower exceeds the credit limit on the loan contract, and 0 otherwise. $F($.$) is the cdf of the standard normal distribution. Distance$ measures and control variables are as those outlined in model (1). As in model (1), we include industry, branch, market and time fixed effects.

If distance proxies for information costs, borrowers located farther away from the lending bank and closer to bank's rivals should face more binding credit limits and thus should be more likely to overdraw funds. Hence, positive coefficient $(\alpha>0)$ on the measure of distance between borrower and lending bank, and negative coefficient on Rivals-Firm Distance $(\beta<0)$, would be consistent with information-based factors rather than transportation costs. By contrast, no association between physical proximity and credit availability would likely reflect transportation costs, properly captured in the price of credit.

\section{Results}

\section{A. Pricing}

We begin the discussion of our results with the analysis of the explicit costs of bank-borrower distance reflected in interest rates. Table 2 presents estimation results based on the specification outlined in Equation (1). In column (1) we include only the variables that capture the distance between borrower and lending bank and between borrower and competing banks. Industry, year, market, and branch fixed effects are also included. In column (2) we augment this baseline specification by including a set of controls for firm and loan characteristics, as well as lending relationship features. Both columns (1) and (2) use the entire sample of loans. In columns (3) and (4) we estimate our augmented model for each of the two years (2004 and 2006) separately. Lastly, in columns (5) and (6) we use panel data estimators to control for unobservable individual effects that could systematically differ across borrowers. We estimate the model from column (2) adopting random effects and Hausman-Taylor estimators.

We note from Table 2 that in all specifications, the coefficient on the variable that captures distance between borrower and lending bank, Branch-Firm Distance, is positive and significant. Both statistical significance and numerical magnitude are robust to alternative specifications, control variables, and estimation techniques. Thus, our preliminary analysis of the impact of 
bank-borrower distance on the cost of credit shows that borrowing firms located farther away from their lending branches pay higher interest rates relative to their counterparts located in the vicinity of the bank. Lack of proximity seems to create incremental cost for the lender transferred onto borrower. The positive association between bank-borrower physical distance and loan rate is consistent with lending practices of marginal cost pricing, where the incremental costs are increasing in distance. Such costs might reflect information collection, evaluation and monitoring, and the higher rate compensates the bank for these additional costs its loan officers incur when dealing with borrowers located farther away.

The coefficient on Rivals-Firm Distance has a sign opposite to that of the coefficient on BranchFirm Distance in each of the specifications in Table 2. When distance between a borrower and rival banks increases, the competition among banks in the local credit market for this borrower diminishes. This allows the lending bank to obtain more precise information. The resultant reduction in severity of asymmetric information problems (e.g., "winner's curse" and adverse selection) makes it feasible for the bank to extend credit at lower price, all else equal.

In addition to being statistically significant, the effects of Branch-Firm Distance and Rivals-Firm Distance are also economically relevant and similar in magnitude to those reported by Degryse and Ongena (2005). For instance, using the estimates in column (2) of Table 2, a change of one standard deviation around the mean in the distance between borrowing firm and lending bank leads to a change in the loan interest rate of almost 12 basis points. Similarly, an increase of one standard deviation in the distance between borrower and rivals' branches decreases the loan rate by about 7 basis points. We note that our panel estimators - random effects model in column (5) and Hausman-Taylor model in column (6) where Credit Limit, Other Services, Relationship Length and Overdraw are assumed to be endogenous covariates - generate results that confirm the association between interest rates and distance.

An examination of the control variables offers some interesting insights. First, the nature of the bank-borrower relationship appears less important for cost of credit. Borrowers with longer lending relationship and with exclusive lending relationship to our bank do not seem to benefit in terms of price. The result contrasts arguments advanced by Boot and Thakor (1994), Petersen and Rajan (1994), Berger and Udell (1995), Chakraborty and Hu (2006), Brick and Palia (2007) and Sakai et al. (2010). However, studies for European countries and Japan show that while credit constraints are lower for firms with long-lasting bank ties, interest rates and collateral requirements in the small business lending context might increase with the length of the lending relationship (e.g. Angelini et al., 1998; Degryse and Van Cayseele, 2000; Hernandez and Martinez, 2006; Ono and Uesugi, 2009; Ogawa et al., 2007). By contrast, consistent with the 
notion that the relationship scope allows banks to accumulate additional information that enhances their ability to assess and monitor customers, we find that the use of other services is often associated with lower interest rates.

As expected, the positive and significant coefficient on Overdraw suggests that overdrawing firms pay higher interest rates. Corporations also tend to pay more. We also note that the largest firms tend to pay less for credit as the coefficient of the indicator for most sales (category 6) is negative and larger in absolute terms compared to the indicators for relatively smaller firms (e.g., category 2 or 3). However, the size effect does not appear to be strictly monotonic.

Credit lines managed at the headquarters are associated with lower interest rates, as shown by the negative and statistically significant coefficient of Decisional Level. This is consistent with a superior cost structure at the headquarters level. Looking at the type of portfolio, we note that credit lines that are considered by the bank as part of its corporate market have lower interest rates compared to those that are part of its small business market.

Collateralization also appears relevant. The negative and significant coefficient of $D$ (Collateral 2) suggests that loans secured by some collateral have lower interest rates, relative to unsecured ones. This effect is consistent with the notion that collateral requirement can serve as a selfselection device leading safer borrowers to select collateralized contracts, and as an incentive mechanisms for borrowers to select safer projects (Besanko and Thakor, 1987; Bester, 1985). However, credit lines with a very high degree of collateralization, i.e. lines with collateral exceeding $80 \%$ of the line, have higher interest rates, as suggested by the positive and significant coefficient on $D$ (Collateral 3). Thus, it appears that high collateral is consistent with the insurance argument (Barro, 1976).

Lastly, we recognize the importance of time invariant characteristics pertaining to branch and market factors. F-tests of the hypotheses that each of the sets of indicators for branch, market, and industry is indistinguishable from 0 , based on the specification in column (2) of the table, reject the null at the $1 \%$-level.

\section{B. The nature of distance costs}

Our analysis shows that distance is important for the price of credit and the positive association between interest rates and bank-borrower distance is consistent with marginal cost pricing and increasing incremental costs. However, whether this effect hinges on transportation costs or information asymmetry frictions remains an open question. To identify the nature of distance costs, we examine in Table 3 the association between borrower-lender proximity and credit availability formalized in Equation (2). In the first specification of Table 3, we estimate a baseline 
Probit model that includes only our distance measures along with industry, year, market, and branch fixed effects. In column (2) we augment the baseline specification by including a wide array of control variables. In columns (3) and (4) we estimate the probit model separately for each year, 2004 and 2006, respectively. Lastly, in columns (5) and (6), we apply random effect and Hausman-Taylor estimators to the augmented model from column (2).

The coefficient of Branch-Firm Distance is positive and statistically significant in all columns of Table 3. Hence, borrowers located farther away from their lending branch are more likely to experience tight credit availability, and thus overdraw funds. The robust positive relationship between distance and credit tightness is in contrast to non-information based arguments for the effect of distance (e.g., transportation costs), where one should observe no link between physical proximity and overdrawing likelihood. The observed association is consistent with informationbased frictions: Bank-borrower distance captures information costs and borrowers located away from the lending bank are more likely to face binding credit limits, and thus overdraw funds.

To quantify the economic importance of distance for the probability of overdrawing, we use the estimates in column (2) of Table 3. A change of one standard deviation around the mean in the distance between borrower and lending bank increases the probability of overdrawing by 2.3\%. A similar increase in the distance between borrower and bank's rivals reduces the probability of overdrawing by $2.4 \%$. Thus, we infer that physical proximity to both lending bank and rivals of the lending bank is economically relevant.

Most of the control variables retain their sign and significance. An important exception is the strong effect of the nature of the lending relationship on the quantity dimension of the loan contract. Borrowers with longer bank relationships seem to benefit in terms of credit availability as they are less likely to overdraw costly funds. The result is consistent with arguments that credit constraints are lower for firms with long-lasting bank ties. Moreover, we also find that borrowers using other services with the bank are less likely to experience binding credit limits. As expected, borrowers of corporate organizational form and larger firms are less likely to overdraw. Similar to our earlier insights, the size effect is not monotonic. The decision-making level is important for the incidence of binding credit limits, as it is for price of credit. Lastly, the collateralization degree is positively associated with the likelihood that the borrower will face binding credit limits.

In sum, borrowers located farther away from their lending branch face tighter credit availability and are more likely to overdraw funds. The positive association between distance and credit availability is consistent with argument for information-based frictions reflected in the cost of distance. 


\section{Sub-sample analyses}

In order to substantiate our arguments about the nature of the costs of distance, we categorize the loans in our sample into sub-samples intended to offer cross-sectional variation in the degree of borrowers' transparency and information asymmetry. The rationale underlying our approach is that if bank-firm distance reflects costs of information asymmetry, its importance should be more pronounced for borrowers more likely to suffer from such problems, i.e. more opaque borrowers. Therefore, we re-estimate the model of credit availability from Equation (2) for each sub-sample and draw inferences from these sub-sample analyses, shown in Panels A and B of Table 4. In each estimation we include the full set of controls used in the estimation of the augmented Probit model in column (2) of Table 3. However, for the sake of brevity, we only report the coefficients of the variables of interest.

The first categorization considers a measure of borrower's overall opacity. It is a common approach to use firm size as proxy for degree of transparency and magnitude of information asymmetry problems. Hence, we split the sample into two groups: borrowing firms with total sales above $€ 5$ million and borrowing firms with total sales below this threshold. ${ }^{6}$ A finding that the relative importance of bank-firm distance is stronger for micro and small business firms would be consistent with our information-based argument. As hypothesized, the coefficient on Branch-Firm Distance is positive and significant only for the sub-sample of "small" firms in column (1) of Panel A. Note from column (2) that for "large" borrowers that are less likely to suffer from information asymmetry problems, distance appears less relevant for the probability of binding credit constraints. Small-sized firms located farther away from their lending branch are more likely to overdraw funds, while large-sized borrowers are unaffected. Hence, as the cost of distance is more pronounced for more opaque firms, this cost is more likely a manifestation of information-based frictions, rather than transportation costs.

The second partition is intended to capture the informational advantage of the lending bank vis-à-vis other banks, i.e. whether the firm has an exclusive lending relationship with the bank (column (3)) or maintains lending relationship with multiple banks (column (4)). The relative importance of bank-borrower distance should be lower for borrowers with an exclusive bank relationship. In this case the bank has an information monopoly and possible concerns about winner's curse should be mitigated. Moreover, the bank could obtain more precise information.

\footnotetext{
${ }^{6}$ This threshold is generally accepted in the literature to identify the range of activities of micro and small business firms. However, the European Commission defines Micro and Small Business Enterprises as firms with turnover of less than $€ 2$ million and $€ 10$ million, respectively. In our case, we are unable to use the cut-off of $€ 10$ million because the categorization system used by the bank is not based on this threshold. We adopt the cut-off of $€ 5$ million because the bank provides only sales categories and the relevant category is 5-25 million.
} 
The sub-sample analysis reveals that distance matters only for borrowers with multiple lending relationships. This finding further corroborates our main insight.

The third partition makes an attempt to use variation in the informational advantage of the lending bank with respect to a borrower, relative to other borrowers of the bank. To this end, we consider the segment where each borrower falls and split the sample into two groups: firms in the small-business portfolio and in the corporate portfolio. For clients in the corporate portfolio, bank loan officers tend to visit firm's premises and negotiate contract terms directly. By contrast, decisions about small-business portfolio are taken at branch premises. The coefficient of BranchFirm Distance is significant only for borrowers in the small-business segment, column (5). Hence, when lenders obtain more precise information about a borrower's activity the importance of physical distance diminishes substantially.

Another set of analyses is reported in Panel B of Table 4. As alternative proxies for opacity, we consider whether the bank has a credit rating for the borrower and whether the credit line is approved and managed at the local bank branch. Ratings capture the credit risk of a borrower and provide an extra layer of information, while proximity of the loan officers at the local bank branches to the socio-economic environment of a borrower facilitates information acquisition and interpretation. Thus, loan officers operating at the local branch could serve as depositary of soft information essential for the design of loan contracts, while the headquarters officers rely predominantly on hard information. Hence, one should observe that the importance of physical distance between lenders and borrowers is less pronounced in the presence of ratings or when decisions are taken at the headquarters. Consistently, the coefficient on Bank-Firm Distance is positive and significant only for the sub-samples of borrowers without rating (column (1)) and borrowers with credit lines managed at the branch level (column (3)).

Our last partition is intended to exploit cross-sectional variation among our borrowers based on information obtained by the bank during its interaction with them. We focus on relationship length. We split the sample into borrowers with short and long lending relationships. A lending relationship is defined as "long" if it exceeds the $75^{\text {th }}$ percentile of lending relationships in the sample. For firms maintaining long-lasting relationships with their bank, loan officers have the opportunity to obtain and accumulate more and more precise information. As expected, distance is significantly related to overdrawing probability only for borrowers without established lending relationships with the bank, as shown in column (5).

Overall, our sub-sample analyses reveal that the importance of distance for the probability that a borrower will experience tight credit availability and rely on the costly option to overdraw expensive funds is more pronounced for sub-samples of firms that are less transparent and more 
likely to suffer from information asymmetry problems. This corroborates our main insight that the cost of distance reflects information-based frictions, rather than pure transportation costs.

\section{Robustness tests}

In what follows, we perform a couple of additional tests to verify the robustness of our findings. First, our sub-sample analyses split the borrowers into groups based on measures intended to capture the magnitude of information asymmetry problems. By and large, our results show that the importance of bank-borrower distance is confined to groups of firms that are more likely to suffer from such problems, e.g. smaller firms, firms without rating, firms without established lending relationship with the bank. Some sub-samples are small and one might interpret the lack of statistical significance as power concerns. To address this concern, we perform the following test. For each partition metric (e.g., size, rating availability, decisional level), we identify the larger and smaller partitions. To ensure that our results are not driven by sample size differences, we match the smaller partition to a stratified random sample from the larger one. Then, we reestimate our models and report the results in Panels A and B of Table 5. Our insights remain qualitatively unchanged.

Second, in the main analysis we capture Rivals-Firm Distance with the 25th percentile of all distances between a borrower and the branches of all banks rivals to our bank in the local credit market. Compared to the minimum distance, the 25th percentile is less sensitive to outliers or possible measurement error. As a robustness test, we re-estimate the specifications from column (2) of Tables 2 and 3 using alternative measures of distance between a borrower and rival banks. Specifically, we consider shortest, average, and median distances. Table 6 shows that our results for the incidence of binding credit constraints, i.e. likelihood of overdrawing, are confirmed. By contrast, the effect of distance to bank's competitors on loan pricing is not robust to alternative measures, consistent with the idea that such distance could have increasing or decreasing impact on mark-up-based rates.

\section{Conclusion}

In this paper we analyze the importance of physical proximity between borrowers and their lending bank for the shape of loan contracts. We first examine the relevance of distance for the cost of credit. Our analysis shows that interest rates increase with borrower-lender distance and decrease with distance between the borrower and lender's rivals in the local credit market. Hence, physical distance seems to represent a cost incurred in the bank-borrower lending 
relationship, especially in the context of banks pricing loans based on marginal costs increasing in distance.

In order to identify economic factors that could justify more expensive loans - information frictions or transportation costs - we explore the quantity dimension of the loan contracts and the probability of tight credit availability and rationing. Our empirical strategy rests on the idea that if distance reflects pure transportation costs, the willingness of banks to extend credit, and the credit constraints borrowers face, should not be affected by their location as transportation costs can be quantified and reflected in the price-setting process more easily. By contrast, if distance reflects information frictions, banks should be prone to extend more (less) credit to nearby (distant) borrowers. To offer insights into the nature of the cost of distance we study the credit tightness faced by borrowers of our bank by focusing on the incidence of overdrawing.

Consistent with the information-based arguments, we find that borrowers' physical locations matter for credit availability. The probability that borrowers will experience binding credit limits increases with bank-borrower distance. Moreover, we confirm that the importance of distance is more pronounced for borrowers that can be considered as less transparent from an information perspective. This corroborates our main insight that distance reflects information-based costs of the bank-firm lending relationship. 


\section{References}

Alessandrini, P., Presbitero, A.F., Zazzaro, A., 2009. Global banking and local markets: A national perspective. Cambridge Journal of Regions, Economy and Society 2, 173-192.

Almazan, A., 2002. A model of competition in banking: Bank capital vs. expertise. Journal of Financial Intermediation 11, 87-121.

Agarwal, S., Hauswald, R., 2010. Distance and private information in lending. Review of Financial Studies 23, 2757-2788.

Angelini, P., Di Salvo R., Ferri, G., 1998. Availability and cost of credit for small businesses: Customer relationships and credit cooperatives. Journal of Banking and Finance 22, 925-954.

Barone, G., Felici, R., Pagnini, M., 2011. Switching costs in local credit markets. International Journal of Industrial Organizations 29, 694-704.

Barro, R.J., 1976. The loan market, collateral, and rates of interest. Journal of Money, Credit and Banking 8, 839-856.

Bellucci, A., Borisov, A., Zazzaro, A., 2010. Does gender matter in bank-firm relationships? Evidence from small business lending. Journal of Banking and Finance 34, 2968-2984.

Berger, A.N., Udell, G.F., 1995. Relationship lending and lines of credit in small firm finance. Journal of Business 68, 351-381.

Besanko, D., Thakor, A., 1987. Collateral and rationing: sorting equilibria in monopolistic and competitive credit markets. International Economic Review 28, 671-89.

Bester, H., 1985. Screening vs. rationing in credit markets with imperfect information. The American Economic Review 75, 850-855.

Boot, A., Thakor, A., 1994. Moral hazard and secured lending in an infinitely repeated credit market game. International Economic Review 35, 899-920.

Brevoort, K.P., Hannan, T.H., 2006. Commercial lending and distance: Evidence from Community Reinvestment Act Data. Journal of Money, Credit and Banking 38, 1991-2012.

Brevoort, K.P., Wolken, J., 2009. Does distance matter in banking? In: Alessandrini, P., Fratianni, M., Zazzaro, A. (Eds.), The Changing Geography of Banking and Finance. Springer, New York.

Brick, I., Palia, D., 2007. Evidence of jointness in the terms of relationship lending. Journal of Financial Intermediation 16, 452-476.

Carling, K., Lundberg, S., 2005. Asymmetric information and distance: An empirical assessment of geographical credit rationing. Journal of Economics and Business 57, 39-59.

Cerqueiro, G., Degryse, H., Ongena, S., 2009. Distance, bank organizational structure, and lending decisions. In: Alessandrini, P., Fratianni, M., Zazzaro, A. (Eds.), The Changing Geography of Banking and Finance. Springer, New York.

Chakraborty, A., Hu, C.X., 2006. Lending relationships in line-of-credit and nonline-of-credit loans: Evidence from collateral use in small business. Journal of Financial Intermediation 15, 86-107.

Chiappori, P.A., Perez-Castrillo, D., Verdier, T., 1995. Spatial competition in the banking system: Localization, cross-subsidies, and the regulation of deposit rates. European Economic Review 39, 889-918.

Cole, R., 1998. The importance of relationships to the availability of credit. Journal of Banking and Finance 22, 959-977.

Degryse, H., Ongena, S., 2005. Distance, lending relationships, and competition. Journal of Finance 60, 231-266.

Degryse, H., Van Cayseele, P., 2000. Relationship lending within a bank-based system: Evidence from European small business data. Journal of Financial Intermediation 9, 90-109.

Degryse, H., Laeven, L., Ongena, S., 2009. The impact of organizational structure and lending technology on banking competition. Review of Finance 13, 225-259. 
Dell'Ariccia, G., Friedman, E., Marquez, R., 1999. Adverse selection as a barrier to entry in the banking industry. The RAND Journal of Economics 30, 515-534.

Dell'Ariccia, G., Marquez, R., 2004. Information and bank credit allocation. Journal of Financial Economics 72, 185-214.

Detragiache, E., Garella, P., Guiso, L., 2002. Multiple versus single banking relationships: Theory and evidence. Journal of Finance 55, 1133-1161.

Gambini, A., Zazzaro, A., 2012. Long-lasting bank relationships and growth of firms. Small Business Economics, forthcoming.

Gehrig, T., 1998. Screening, cross-border banking, and the allocation of credit. Research in Economics 52, 387-407.

Giannetti, M., Yafeh, Y., 2012. Do cultural differences between contracting parties matter? Evidence from syndicated bank loans. Management Science 58, 365-383.

Hauswald, R., Marquez, R., 2003. Information technology and financial services competition. Review of Financial Studies 16, 921-948.

Hauswald, R., Marquez, R., 2006. Competition and strategic information acquisition in credit market. Review of Financial Studies 19, 967-1000.

Hernandez, G., Martinez, P., 2006. Banking relationships: Effects on the debt terms for small Spanish firms. Journal of Small Business Management 44, 315-333.

Knyazeva, A., Knyazeva, D., 2012. Does being your bank's neighbor matter? Journal of Banking and Finance 36, 1194-1209.

Lederer, P.J., Hurter, A.P., 1986. Competition of firms: Discriminatory pricing and location. Econometrica 54, 623-640.

Liberti, J. M., Mian, A., 2009. Estimating the effect of hierarchies. Review of Financial Studies 22, 4057-4090.

Ogawa, K., Sterken, E., Tokutsu, I., 2007. Why do Japanese firms prefer multiple bank relationship? Some evidence from firm-level data. Economic Systems 31, 49-70.

Ono, A., Uesugi, I., 2009. The role of collateral and personal guarantees in relationship lending: Evidence from Japan's small business loan market. Journal of Money, Credit and Banking 41, 935-960.

Petersen, M.A., Rajan, R.G., 1994. The benefits of firm-creditor relationships: Evidence from small-business data, Journal of Finance 49, 3-37.

Petersen, M.A., Rajan, R.G., 2002. Does distance still matter? The information revolution in small business lending. Journal of Finance 57, 2533-2570.

Sakai, K., Uesugi, I., Watanabe, T., 2010. Firm age and the evolution of borrowing costs: Evidence from Japanese small firms. Journal of Banking and Finance 34, 1970-1981.

Shaffer, S., 1998. The winner's curse in banking. Journal of Financial Intermediation 7, 359-392.

Stein, J., 2002. Information production and capital allocation: Decentralized versus hierarchical firms. Journal of Finance 57, 1891-1922.

Sussman, O., Zeira, J., 1995. Banking and development, CEPR Discussion Paper 1127. 
Table 1 Summary Statistics

\begin{tabular}{|c|c|c|c|}
\hline & $\begin{array}{l}\text { Observations } \\
\text { (1) }\end{array}$ & $\begin{array}{c}\text { Mean } \\
(2)\end{array}$ & $\begin{array}{l}\text { St. dev. } \\
\text { (3) }\end{array}$ \\
\hline \multicolumn{4}{|l|}{ Dependent V ariables } \\
\hline Interest Rate & 15,077 & 7.06 & $(2.47)$ \\
\hline Overdraw & 14,899 & 0.22 & $(0.42)$ \\
\hline \multicolumn{4}{|l|}{ Distance Variables } \\
\hline Branch-Firm Distance (meters) & 15,077 & 4,977 & $(7,266)$ \\
\hline Rivals-Firm Distance (meters) & 15,077 & 3,338 & $(4,438)$ \\
\hline \multicolumn{4}{|l|}{ Control Variables } \\
\hline Corporation & 15,077 & 0.33 & $(0.47)$ \\
\hline Sales & 14,990 & 2.18 & $(1.55)$ \\
\hline $\mathrm{D}($ Sales 1) & 14,990 & 0.55 & $(0.49)$ \\
\hline $\mathrm{D}($ Sales 2) & 14,990 & 0.11 & $(0.31)$ \\
\hline $\mathrm{D}($ Sales 3) & 14,990 & 0.15 & $(0.35)$ \\
\hline $\mathrm{D}($ Sales 4) & 14,990 & 0.12 & $(0.32)$ \\
\hline $\mathrm{D}($ Sales 5) & 14,990 & 0.08 & $(0.28)$ \\
\hline $\mathrm{D}($ Sales 6) & 14,990 & 0.03 & $(0.16)$ \\
\hline Credit Limit & 14,901 & 86,511 & $(323,685)$ \\
\hline Credit Used & 14,989 & 62,268 & $(234,420)$ \\
\hline Relationship Length (days) & 14,990 & 3,360 & $(2,714)$ \\
\hline Multiple Lending & 15,077 & 0.96 & $(0.20)$ \\
\hline Other Services & 15,077 & 0.91 & $(0.29)$ \\
\hline Portfolio & 15,077 & 0.09 & $(0.29)$ \\
\hline Decisional Level & 15,077 & 0.17 & $(0.38)$ \\
\hline Collateral & 15,077 & 1.42 & $(0.68)$ \\
\hline $\mathrm{D}$ (Collateral 1) & 15,077 & 0.70 & $(0.46)$ \\
\hline $\mathrm{D}$ (Collateral 2) & 15,077 & 0.19 & $(0.39)$ \\
\hline D(Collateral 3) & 15,077 & 0.11 & $(0.32)$ \\
\hline Rating & 8,539 & 0.16 & $(0.37)$ \\
\hline
\end{tabular}

Note: The table presents summary statistics for the sample used in the multivariate analysis. The definition and construction of each variable is provided in the Appendix. Column (1) shows the number of observations, while column (2) shows the mean value for each variable. The last column shows in parentheses the standard deviation for each variable. 
Table 2 Distance and Price of Credit

\begin{tabular}{|c|c|c|c|c|c|c|}
\hline & $(1)$ & $(2)$ & (3) & (4) & $(5)$ & $(6)$ \\
\hline \multirow[t]{2}{*}{ Branch-Firm Distance } & $0.062 * * *$ & $0.067 * * *$ & $0.068^{* *}$ & $0.059 * *$ & $0.069 * * *$ & $0.067 * * *$ \\
\hline & $(0.018)$ & $(0.018)$ & $(0.028)$ & $(0.023)$ & $(0.020)$ & $(0.021)$ \\
\hline \multirow[t]{2}{*}{ Rivals-Firm Distance } & $-0.079 * * *$ & $-0.046^{* *}$ & -0.036 & $-0.048^{*}$ & $-0.056^{* *}$ & $-0.057 * *$ \\
\hline & $(0.021)$ & $(0.021)$ & $(0.033)$ & $(0.027)$ & $(0.024)$ & $(0.025)$ \\
\hline \multirow[t]{2}{*}{ Corporation } & & $0.242 * * *$ & $0.476 * * *$ & 0.056 & $0.190 * * *$ & $0.180 * * *$ \\
\hline & & $(0.052)$ & $(0.083)$ & $(0.066)$ & $(0.063)$ & $(0.067)$ \\
\hline \multirow[t]{2}{*}{$\mathrm{D}$ (Sales 2) } & & $-0.214 * * *$ & $-0.237 * *$ & $-0.198^{* *}$ & $-0.217 * *$ & $-0.209 * *$ \\
\hline & & $(0.067)$ & $(0.106)$ & $(0.086)$ & $(0.085)$ & $(0.087)$ \\
\hline \multirow[t]{2}{*}{$\mathrm{D}($ Sales 3) } & & $-0.231 * * *$ & $-0.201 * *$ & $-0.252^{* * *}$ & $-0.256^{* * *}$ & $-0.236 * * *$ \\
\hline & & $(0.060)$ & $(0.093)$ & $(0.078)$ & $(0.079)$ & $(0.081)$ \\
\hline \multirow[t]{2}{*}{$\mathrm{D}$ (Sales 4) } & & -0.018 & 0.016 & -0.049 & -0.051 & -0.018 \\
\hline & & $(0.075)$ & $(0.119)$ & $(0.097)$ & $(0.094)$ & $(0.096)$ \\
\hline \multirow[t]{2}{*}{$\mathrm{D}$ (Sales 5) } & & $-0.177^{*}$ & -0.218 & -0.151 & -0.145 & -0.139 \\
\hline & & $(0.101)$ & $(0.160)$ & $(0.129)$ & $(0.136)$ & $(0.140)$ \\
\hline \multirow[t]{2}{*}{$\mathrm{D}$ (Sales 6) } & & $-0.418^{* * *}$ & $-0.537 * *$ & $-0.339 * *$ & $-0.392 *$ & -0.309 \\
\hline & & $(0.144)$ & $(0.244)$ & $(0.171)$ & $(0.221)$ & $(0.235)$ \\
\hline \multirow[t]{2}{*}{ Multiple Lending } & & 0.081 & & 0.023 & 0.079 & 0.081 \\
\hline & & $(0.105)$ & & $(0.106)$ & $(0.085)$ & $(0.094)$ \\
\hline \multirow[t]{2}{*}{ Other Services } & & $-0.165^{*}$ & 0.057 & $-0.305^{* * *}$ & $-0.281 * * *$ & $-0.284 * * *$ \\
\hline & & $(0.086)$ & $(0.142)$ & $(0.108)$ & $(0.087)$ & $(0.090)$ \\
\hline \multirow[t]{2}{*}{ Relationship Length } & & -0.017 & 0.042 & $-0.127 * * *$ & -0.028 & -0.051 \\
\hline & & $(0.024)$ & $(0.033)$ & $(0.036)$ & $(0.023)$ & $(0.033)$ \\
\hline \multirow{2}{*}{ Portfolio } & & $-0.530^{* * *}$ & $-0.462^{* * *}$ & $-0.595^{* * *}$ & $-0.544 * * *$ & $-0.486 * * *$ \\
\hline & & $(0.090)$ & $(0.145)$ & $(0.114)$ & $(0.131)$ & $(0.136)$ \\
\hline \multirow[t]{2}{*}{ Decisional Level } & & $-0.245^{* * *}$ & $-0.211 * *$ & $-0.262^{* * *}$ & $-0.272^{* * *}$ & $-0.254 * * *$ \\
\hline & & $(0.063)$ & $(0.102)$ & $(0.080)$ & $(0.070)$ & $(0.073)$ \\
\hline \multirow[t]{2}{*}{ Credit Limit } & & $-0.000^{* * *}$ & -0.000 & $-0.000^{* * *}$ & $-0.000^{* *}$ & $-0.000^{* *}$ \\
\hline & & $(0.000)$ & $(0.000)$ & $(0.000)$ & $(0.000)$ & $(0.000)$ \\
\hline \multirow[t]{2}{*}{ Overdraw } & & $0.397 * * *$ & $0.384 * * *$ & $0.414 * * *$ & $0.228 * * *$ & 0.065 \\
\hline & & $(0.053)$ & $(0.086)$ & $(0.066)$ & $(0.042)$ & $(0.053)$ \\
\hline \multirow[t]{2}{*}{ D(Collateral 2) } & & $-0.327 * * *$ & $-0.366^{* * *}$ & $-0.353^{* * *}$ & $-0.163^{* * *}$ & $-0.148 * * *$ \\
\hline & & $(0.047)$ & $(0.094)$ & $(0.056)$ & $(0.044)$ & $(0.044)$ \\
\hline \multirow[t]{2}{*}{$\mathrm{D}$ (Collateral 3) } & & $0.525^{* * *}$ & $0.538^{* * *}$ & $0.389 * * *$ & $0.381^{* * *}$ & $0.371 * * *$ \\
\hline & & $(0.080)$ & $(0.174)$ & $(0.091)$ & $(0.060)$ & $(0.061)$ \\
\hline \multirow[t]{2}{*}{ Constant } & $5.031 * * *$ & $4.685^{* * *}$ & $5.124^{* * *}$ & $8.306^{* * *}$ & $7.149 * * *$ & $6.042 * * *$ \\
\hline & $(0.635)$ & $(0.692)$ & $(0.544)$ & $(0.541)$ & $(0.360)$ & $(0.824)$ \\
\hline Industry Effects & Yes & Yes & Yes & Yes & Yes & Yes \\
\hline Time Effects & Yes & Yes & No & No & Yes & Yes \\
\hline Branch Effects & Yes & Yes & No & No & Yes & Yes \\
\hline Market Effects & Yes & Yes & Yes & Yes & Yes & Yes \\
\hline Observations & 14,729 & 14,501 & 6,223 & 8,278 & 14,501 & 14,501 \\
\hline R-squared & 0.06 & 0.09 & 0.04 & 0.07 & 0.09 & \\
\hline
\end{tabular}

Note: The table presents multivariate analysis of the impact of distance on Interest Rate. Column (1) shows results of a baseline pooled OLS regression with dependent variable the interest rate charged by the bank. Column (2) shows results of an augmented OLS regression. Columns (3) and (4) show results for years 2004 and 2006, respectively. Column (5) shows results of a Random Effects model. Column (6) shows results of Hausman-Taylor estimation with Relationship Length, Credit Limit, Overdraw and Multiple Lending as endogenous variables. The table reports point estimates of the coefficients, followed in parentheses by robust standard errors. The definition and construction of the variables is provided in the Appendix. ${ }^{*} \mathrm{p}<0.1,{ }^{* *} \mathrm{p}<0.05,{ }^{* * *} \mathrm{p}<0.01$ 
Table 3 Distance and Credit Availability

\begin{tabular}{|c|c|c|c|c|c|c|}
\hline & (1) & (2) & (3) & (4) & (5) & (6) \\
\hline \multirow[t]{2}{*}{ Branch-Firm Distance } & $0.042 * * *$ & $0.044 * * *$ & $0.052^{* * *}$ & $0.038^{* * *}$ & $0.013^{* * *}$ & $0.014 * * *$ \\
\hline & $(0.010)$ & $(0.010)$ & $(0.016)$ & $(0.013)$ & $(0.003)$ & $(0.003)$ \\
\hline \multirow[t]{2}{*}{ Rivals-Firm Distance } & $-0.071 * * *$ & $-0.054 * * *$ & $-0.058^{* * *}$ & $-0.049 * * *$ & $-0.016^{* * *}$ & $-0.017 * * *$ \\
\hline & $(0.012)$ & $(0.012)$ & $(0.019)$ & $(0.016)$ & $(0.004)$ & $(0.004)$ \\
\hline \multirow[t]{2}{*}{ Corporation } & & $-0.135^{* * *}$ & $-0.226^{* * *}$ & $-0.076^{*}$ & $-0.037 * * *$ & $-0.037 * * *$ \\
\hline & & $(0.032)$ & $(0.050)$ & $(0.042)$ & $(0.010)$ & $(0.010)$ \\
\hline \multirow[t]{2}{*}{$\mathrm{D}$ (Sales 2) } & & 0.022 & $0.130^{* *}$ & -0.047 & -0.005 & -0.003 \\
\hline & & $(0.042)$ & $(0.063)$ & $(0.056)$ & $(0.014)$ & $(0.014)$ \\
\hline \multirow[t]{2}{*}{$\mathrm{D}$ (Sales 3) } & & $-0.078^{*}$ & -0.057 & -0.077 & $-0.026^{* *}$ & $-0.026^{* *}$ \\
\hline & & $(0.040)$ & $(0.061)$ & $(0.053)$ & $(0.013)$ & $(0.013)$ \\
\hline \multirow[t]{2}{*}{$\mathrm{D}($ Sales 4) } & & 0.005 & 0.054 & -0.018 & -0.005 & -0.005 \\
\hline & & $(0.048)$ & $(0.074)$ & $(0.063)$ & $(0.015)$ & $(0.015)$ \\
\hline \multirow[t]{2}{*}{$\mathrm{D}($ Sales 5) } & & -0.086 & -0.016 & -0.121 & -0.023 & -0.023 \\
\hline & & $(0.074)$ & $(0.109)$ & $(0.100)$ & $(0.022)$ & $(0.022)$ \\
\hline \multirow[t]{2}{*}{$\mathrm{D}($ Sales 6) } & & $-0.393^{* * *}$ & $-0.338^{*}$ & $-0.389 * *$ & $-0.077 * *$ & $-0.067^{*}$ \\
\hline & & $(0.131)$ & $(0.202)$ & $(0.172)$ & $(0.035)$ & $(0.036)$ \\
\hline \multirow[t]{2}{*}{ Multiple Lending } & & 0.087 & & 0.069 & 0.022 & 0.016 \\
\hline & & $(0.072)$ & & $(0.073)$ & $(0.018)$ & $(0.022)$ \\
\hline \multirow[t]{2}{*}{ Other Services } & & $-0.181 * * *$ & $-0.268^{* * *}$ & $-0.131^{* *}$ & $-0.067 * * *$ & $-0.073^{* * *}$ \\
\hline & & $(0.042)$ & $(0.068)$ & $(0.054)$ & $(0.014)$ & $(0.015)$ \\
\hline \multirow[t]{2}{*}{ Relationship Length } & & $-0.115^{* * *}$ & $-0.082^{* * *}$ & $-0.159 * * *$ & $-0.027 * * *$ & $-0.019 * * *$ \\
\hline & & $(0.013)$ & $(0.017)$ & $(0.021)$ & $(0.004)$ & $(0.007)$ \\
\hline \multirow{2}{*}{ Portfolio } & & 0.092 & 0.126 & 0.069 & 0.021 & 0.025 \\
\hline & & $(0.072)$ & $(0.106)$ & $(0.097)$ & $(0.021)$ & $(0.021)$ \\
\hline \multirow[t]{2}{*}{ Decisional Level } & & $-0.382^{* * *}$ & $-0.384 * * *$ & $-0.374 * * *$ & $-0.091 * * *$ & $-0.087 * * *$ \\
\hline & & $(0.046)$ & $(0.070)$ & $(0.060)$ & $(0.012)$ & $(0.013)$ \\
\hline \multirow[t]{2}{*}{$\mathrm{D}$ (Collateral 2) } & & $0.111^{* * *}$ & $0.120^{*}$ & $0.128^{* * *}$ & $0.026^{* * *}$ & $0.026^{* * *}$ \\
\hline & & $(0.033)$ & $(0.067)$ & $(0.039)$ & $(0.009)$ & $(0.009)$ \\
\hline \multirow[t]{2}{*}{$\mathrm{D}$ (Collateral 3) } & & $0.494 * * *$ & 0.138 & $0.576^{* * *}$ & $0.149 * * *$ & $0.148^{* * *}$ \\
\hline & & $(0.039)$ & $(0.086)$ & $(0.046)$ & $(0.012)$ & $(0.012)$ \\
\hline \multirow[t]{2}{*}{ Constant } & $-106.936 * * *$ & 0.147 & 0.148 & $0.438 *$ & $0.456^{* * *}$ & $0.495^{* * *}$ \\
\hline & $(24.066)$ & $(0.176)$ & $(0.231)$ & $(0.249)$ & $(0.054)$ & $(0.132)$ \\
\hline Industry Effects & Yes & Yes & Yes & Yes & Yes & Yes \\
\hline Time Effects & Yes & Yes & No & No & Yes & Yes \\
\hline Branch Effects & Yes & Yes & No & No & Yes & Yes \\
\hline Market Effects & Yes & Yes & Yes & Yes & Yes & Yes \\
\hline Observations & 14,560 & 14,501 & 6,223 & 8,278 & 14,501 & 14,501 \\
\hline R-squared & 0.03 & 0.07 & 0.06 & 0.09 & 0.10 & \\
\hline
\end{tabular}

Note: The table presents multivariate analysis of the impact of distance on Overdraw. Column (1) shows results of a baseline Probit model with dependent variable that takes the value of 1 if the firm exceeds the amount granted on the credit line by the bank and 0 otherwise. Column (2) shows results of an augmented Probit model. Columns (3) and (4) show results for years 2004 and 2006, respectively. Column (5) shows results of a Random Effects model. Column (6) shows results of Hausman-Taylor estimation with Relationship Length and Multiple Lending as endogenous variable. The table reports point estimates of the coefficients, followed in parentheses by robust standard errors. The definition and construction of the variables is provided in the Appendix. ${ }^{*} \mathrm{p}<0.1,{ }^{* *} \mathrm{p}<0.05,{ }^{* * *} \mathrm{p}<0.01$ 
Table 4 Distance and Credit Availability - Sub-sample Analyses

Panel A

\begin{tabular}{lcccccc}
\hline & \multicolumn{2}{c}{ Sales } & \multicolumn{2}{c}{ Multi-lending } & \multicolumn{2}{c}{ Portfolio } \\
& $<5 \mathrm{M}$ & $>5 \mathrm{M}$ & Multiple & Exclusive & SBs & Corporate \\
& $(1)$ & $(2)$ & $(3)$ & $(4)$ & $(5)$ & $(6)$ \\
\hline Branch-Firm Distance & $0.044^{* * *}$ & 0.049 & $0.045^{* * *}$ & 0.045 & $0.045^{* * *}$ & -0.051 \\
& $(0.010)$ & $(0.051)$ & $(0.010)$ & $(0.072)$ & $(0.010)$ & $(0.053)$ \\
Rivals-Firm Distance & $-0.055^{* * *}$ & -0.031 & $-0.056^{* * *}$ & 0.045 & $-0.056^{* * *}$ & 0.032 \\
& $(0.012)$ & $(0.067)$ & $(0.012)$ & $(0.084)$ & $(0.012)$ & $(0.067)$ \\
Controls & Yes & Yes & Yes & Yes & Yes & Yes \\
Industry Effects & Yes & Yes & Yes & Yes & Yes & Yes \\
Time Effects & Yes & Yes & Yes & Yes & Yes & Yes \\
Branch Effects & Yes & Yes & Yes & Yes & Yes & Yes \\
Market Effects & Yes & Yes & Yes & Yes & Yes & Yes \\
Observations & 13,072 & 1,327 & 14,034 & 399 & 13,176 & 1,103 \\
R-squared & 0.06 & 0.13 & 0.07 & 0.20 & 0.06 & 0.14 \\
\hline
\end{tabular}

Panel B

\begin{tabular}{lcccccc}
\hline & \multicolumn{2}{c}{ Rating } & \multicolumn{2}{c}{ Decisional Level } & \multicolumn{2}{c}{ Relationship Length } \\
& No rating & Rating & Branch & HQs & Short & Long \\
& $(1)$ & $(2)$ & $(3)$ & $(4)$ & $(5)$ & $(6)$ \\
\hline Branch-Firm Distance & $0.049^{* * *}$ & -0.040 & $0.046^{* * *}$ & 0.017 & $0.048^{* * *}$ & $0.041^{*}$ \\
& $(0.014)$ & $(0.041)$ & $(0.011)$ & $(0.033)$ & $(0.011)$ & $(0.024)$ \\
Rivals-Firm Distance & $-0.048^{* * *}$ & -0.056 & $-0.053^{* * *}$ & -0.043 & $-0.048^{* * *}$ & $-0.090^{* * *}$ \\
& $(0.017)$ & $(0.049)$ & $(0.013)$ & $(0.039)$ & $(0.013)$ & $(0.027)$ \\
Controls & Yes & Yes & Yes & Yes & Yes & Yes \\
Industry Effects & Yes & Yes & Yes & Yes & Yes & Yes \\
Time Effects & No & No & Yes & Yes & Yes & Yes \\
Branch Effects & Yes & Yes & Yes & Yes & Yes & Yes \\
Market Effects & Yes & Yes & Yes & Yes & Yes & Yes \\
Observations & 6,935 & 1,302 & 12,139 & 2,271 & 10,823 & 3,708 \\
R-squared & 0.09 & 0.12 & 0.06 & 0.09 & 0.06 & 0.08 \\
\hline
\end{tabular}

Note: The table presents sub-sample analyses of the impact of distance on Overdraw. Columns (1) and (2) of Panel A show results for sub-samples of borrowers with sales higher and lower than $€ 5$ million, respectively. Columns (3) and (4) of Panel A show results for sub-samples of borrowers with multiple and exclusive lending relationship, respectively. Columns (5) and (6) of Panel A show results for sub-samples of borrowers that are part of the smallbusiness and corporate portfolios, respectively. Columns (1) and (2) of Panel B show results for sub-samples of borrowers with and without rating by the bank. In this analysis we use only 2006 because the bank made available its ratings for this year only. Columns (3) and (4) of Panel B show results for sub-samples of borrowers where the credit line is managed at the local branches and headquarters, respectively. Columns (5) and (6) of Panel B show results for sub-samples of borrowers with short and long lending relationship with the bank, respectively. A lending relationship is defined as long if its length exceeds the $75^{\text {th }}$ percentile of the bank-borrower lending relationships in the sample. Unless otherwise indicated, each regression uses the entire period and includes industry, time, branch, and market effects. The table reports point estimates of the coefficients, followed in parentheses by robust standard errors. The definition and construction of the variables is provided in the Appendix. ${ }^{*} \mathrm{p}<0.1,{ }^{* *} \mathrm{p}<0.05,{ }^{* * *} \mathrm{p}<0.01$ 
Table 5 Distance and Credit Availability - Stratified Sub-sample Analyses

Panel A

\begin{tabular}{lcccccc}
\hline & \multicolumn{2}{c}{ Sales } & \multicolumn{2}{c}{ Multi-lending } & \multicolumn{2}{c}{ Portfolio } \\
& $<5 \mathrm{M}$ & $>5 \mathrm{M}$ & Multiple & Exclusive & SBs & Corporate \\
& $(1)$ & $(2)$ & $(3)$ & $(4)$ & $(5)$ & $(6)$ \\
\hline Branch-Firm Distance & $0.050^{*}$ & 0.049 & 0.050 & 0.045 & $0.053^{* *}$ & -0.051 \\
& $(0.028)$ & $(0.051)$ & $(0.054)$ & $(0.072)$ & $(0.026)$ & $(0.053)$ \\
Rivals-Firm Distance & -0.053 & -0.031 & -0.111 & 0.045 & $-0.108^{* * *}$ & 0.032 \\
& $(0.034)$ & $(0.067)$ & $(0.074)$ & $(0.084)$ & $(0.033)$ & $(0.067)$ \\
Controls & Yes & Yes & Yes & Yes & Yes & Yes \\
Industry Effects & Yes & Yes & Yes & Yes & Yes & Yes \\
Time Effects & Yes & Yes & Yes & Yes & Yes & Yes \\
Branch Effects & Yes & Yes & Yes & Yes & Yes & Yes \\
Market Effects & Yes & Yes & Yes & Yes & Yes & Yes \\
Observations & 2,016 & 1,327 & 557 & 399 & 2,482 & 1,103 \\
R-squared & 0.10 & 0.13 & 0.17 & 0.20 & 0.09 & 0.14 \\
\hline
\end{tabular}

\section{Panel B}

\begin{tabular}{lcccccc}
\hline & \multicolumn{2}{c}{ Rating } & \multicolumn{2}{c}{ Decisional Level } & \multicolumn{2}{c}{ Relationship Length } \\
& No rating & Rating & Branch & HQs & Short & Long \\
& $(1)$ & $(2)$ & $(3)$ & $(4)$ & $(5)$ & $(6)$ \\
\hline Branch-Firm Distance & $0.072^{*}$ & -0.040 & $0.102^{* * *}$ & 0.017 & $0.069^{* * *}$ & $0.041^{*}$ \\
& $(0.037)$ & $(0.041)$ & $(0.025)$ & $(0.033)$ & $(0.020)$ & $(0.024)$ \\
Rivals-Firm Distance & $-0.105^{* *}$ & -0.056 & $-0.100^{* * *}$ & -0.043 & $-0.052^{* *}$ & $-0.090^{* * *}$ \\
& $(0.045)$ & $(0.049)$ & $(0.031)$ & $(0.039)$ & $(0.024)$ & $(0.027)$ \\
Controls & Yes & Yes & Yes & Yes & Yes & Yes \\
Industry Effects & Yes & Yes & Yes & Yes & Yes & Yes \\
Time Effects & No & No & Yes & Yes & Yes & Yes \\
Branch Effects & Yes & Yes & Yes & Yes & Yes & Yes \\
Market Effects & Yes & Yes & Yes & Yes & Yes & Yes \\
Observations & 1,149 & 1,302 & 2,497 & 2,271 & 3,888 & 3,708 \\
R-squared & 0.13 & 0.12 & 0.09 & 0.09 & 0.08 & 0.08 \\
\hline
\end{tabular}

Note: The table presents sub-sample analyses of the impact of distance on Overdraw. Columns (1) and (2) of Panel A show results for sub-samples of borrowers with sales higher and lower than $€ 5$ million, respectively. Columns (3) and (4) of Panel A show results for sub-samples of borrowers with multiple and exclusive lending relationship, respectively. Columns (5) and (6) of Panel A show results for sub-samples of borrowers that are part of the smallbusiness and corporate portfolios, respectively. Columns (1) and (2) of Panel B show results for sub-samples of borrowers with and without rating by the bank. In this analysis we use only 2006 because the bank made available its rating only for this year. Columns (3) and (4) of Panel B show results for sub-samples of borrowers where the credit line is managed at the local branches and headquarters, respectively. Columns (5) and (6) of Panel B show results for sub-samples of borrowers with short and long lending relationship with the bank, respectively. A lending relationship is defined as long if its length exceeds the $75^{\text {th }}$ percentile of the bank-borrower lending relationships in the sample. Unless otherwise indicated, each regression uses the entire period and includes industry, time, branch, and market effects. The table reports point estimates of the coefficients, followed in parentheses by robust standard errors. The definition and construction of the variables is provided in the Appendix. ${ }^{*} \mathrm{p}<0.1,{ }^{* *} \mathrm{p}<0.05,{ }^{* * *} \mathrm{p}<0.01$ 
Table 6: Alternative Measure of Distance to Bank Rivals

\begin{tabular}{|c|c|c|c|c|c|c|}
\hline & \multicolumn{3}{|c|}{ Dependent Variable: Interest Rate } & \multicolumn{3}{|c|}{ Dependent variable: Overdraw } \\
\hline & $(1)$ & (2) & (3) & (4) & (5) & (6) \\
\hline \multirow[t]{2}{*}{ Branch-Firm Distance } & $0.059 * * *$ & $0.065^{* * *}$ & $0.066^{* * *}$ & $0.033^{* * *}$ & $0.038^{* * *}$ & $0.033^{* * *}$ \\
\hline & $(0.016)$ & $(0.017)$ & $(0.017)$ & $(0.009)$ & $(0.010)$ & $(0.010)$ \\
\hline \multirow[t]{2}{*}{ Rivals-Firm Min Distance } & -0.011 & & & $-0.027 * * *$ & & \\
\hline & $(0.011)$ & & & $(0.006)$ & & \\
\hline Rivals-Firm Med Distance & & -0.033 & & & $-0.048^{* * *}$ & \\
\hline & & $(0.023)$ & & & $(0.013)$ & \\
\hline \multirow[t]{2}{*}{ Rivals-Firm Mean Distance } & & & -0.042 & & & $-0.035^{* *}$ \\
\hline & & & $(0.025)$ & & & $(0.015)$ \\
\hline Controls & Yes & Yes & Yes & Yes & Yes & Yes \\
\hline Industry Effects & Yes & Yes & Yes & Yes & Yes & Yes \\
\hline Time Effects & Yes & Yes & Yes & Yes & Yes & Yes \\
\hline Branch Effects & Yes & Yes & Yes & Yes & Yes & Yes \\
\hline Market Effects & Yes & Yes & Yes & Yes & Yes & Yes \\
\hline Observations & 14,557 & 14,557 & 14,557 & 14,557 & 14,557 & 14,557 \\
\hline R-squared & 0.09 & 0.09 & 0.09 & 0.07 & 0.07 & 0.07 \\
\hline
\end{tabular}

Note: The table presents multivariate analysis of the impact of alternative measures of Rivals-Firm Distance on Interest Rate and Overdraw. Columns (1) through (3) show results of the augmented OLS model with dependent variable Interest Rate. Column (1) uses the shortest Rivals-Firm distance, column (2) uses the median Rivals-Firm distance, and column (3) uses the average Rivals-Firm distance. Columns (4) through (6) show results of the augmented Probit model with dependent variable Overdraw. Each regression uses the entire sample and includes industry, time, branch, and market effects. The table reports point estimates of the coefficients, followed in parentheses by robust standard errors. The definition and construction of the variables is provided in the Appendix. $* \mathrm{p}<0.1, * * \mathrm{p}<0.05$, $* * * \mathrm{p}<0.01$ 


\section{Appendix: List of Variables}

\begin{tabular}{|c|c|}
\hline Variable & Definition \\
\hline Interest Rate & The interest rate charged by the bank, expressed as percentage. \\
\hline Overdraw & $\begin{array}{l}\text { An indicator variable that takes value of } 1 \text { if the borrower uses more than the } \\
\text { amount granted on the credit line by the bank and } 0 \text { otherwise. }\end{array}$ \\
\hline Branch-Firm Distance & Natural logarithm of the metric distance between borrower and lending branch. \\
\hline Rivals-Firm Distance & $\begin{array}{l}\text { Natural logarithm of the 25th percentile of the metric distances between } \\
\text { borrower and bank branches of competing banks in the local credit market }\end{array}$ \\
\hline Sales & $\begin{array}{l}\text { A step variable that takes the value of } 1 \text { if borrower's sales are below } € 250,000 ; 2 \\
\text { for sales between } € 250,000 \text { and } € 1,500,000 ; 3 \text { for sales between } € 1,500,000 \text { and } \\
€ 5,000,000 ; 4 \text { for sales between } € 5,000,000 \text { and } € 25,000,000 \text {; and } 5 \text { for sales } \\
\text { between } € 25,000,000 \text { and } € 50,000,000 \text {. }\end{array}$ \\
\hline $\mathrm{D}$ (Sales i) & $\begin{array}{l}\text { An indicator variable that takes the value of } 1 \text { if the firm's sales fall in the } i \text {-th } \\
\text { category ( } 1 \text { through } 5) \text { and } 0 \text { otherwise. }\end{array}$ \\
\hline Multiple Lending & $\begin{array}{l}\text { An indicator variable that takes the value of } 1 \text { if a borrower maintains lending } \\
\text { relationships with multiple banks and } 0 \text { if the borrower has an exclusive lending } \\
\text { relationship with the bank. }\end{array}$ \\
\hline Other Services & $\begin{array}{l}\text { An indicator variable that takes the value of } 1 \text { if the bank branch provides other } \\
\text { services (besides the credit line) to the borrower and } 0 \text { otherwise. }\end{array}$ \\
\hline Relationship Length & $\begin{array}{l}\text { A continuous variable that measures the length of the bank-borrower lending } \\
\text { relationship. Constructed as the natural logarithm of } 1+\text { the length of the bank- } \\
\text { borrower relationship expressed in days. }\end{array}$ \\
\hline Decisional Level & $\begin{array}{l}\text { An indicator variable that takes the value of } 1 \text { if the credit line is managed at the } \\
\text { headquarters level and } 0 \text { if this happens at a local bank branch. }\end{array}$ \\
\hline Collateral & $\begin{array}{l}\text { A step variable that takes the value of } 1 \text { if the credit line is not secured with } \\
\text { collateral, } 2 \text { if the line is secured with collateral of less than } 80 \% \text { of the credit line, } \\
\text { and } 3 \text { if the collateralization is above } 80 \% \text {. }\end{array}$ \\
\hline $\mathrm{D}($ Collateral i) & $\begin{array}{l}\text { An indicator variable that takes the value of } 1 \text { if the collateralization of the credit } \\
\text { line is in the } i \text {-th category ( } 1 \text { through } 3 \text { ) and } 0 \text { otherwise. }\end{array}$ \\
\hline Portfolio & $\begin{array}{l}\text { An indicator that takes the value of } 1 \text { if the bank considers the credit line as part } \\
\text { of its small-business portfolio and } 0 \text { if it is part of the corporate portfolio. }\end{array}$ \\
\hline Credit Limit & $\begin{array}{l}\text { A continuous variable that measures the amount of credit granted by the bank. } \\
\text { Constructed as the natural logarithm of the total credit line amount. }\end{array}$ \\
\hline Corporation & $\begin{array}{l}\text { An indicator variable that takes the value of } 1 \text { if the borrower has corporate } \\
\text { organizational form and } 0 \text { otherwise }\end{array}$ \\
\hline
\end{tabular}

